\title{
IMPLEMENTASI E-PROCUREMENT DITINJAU DARI KESUKSESAN SISTEM TEKNOLOGI INFORMASI DENGAN MENGGUNAKAN MODEL DELONE DAN MCLEAN
}

\author{
Yunus Harjito \\ Fakultas Ekonomi dan Bisnis, Universitas Muhammadiyah Surakarta \\ yunus_accounting@yahoo.co.id \\ Fatchan Achyani \\ Fakultas Ekonomi dan Bisnis, Universitas Muhammadiyah Surakarta \\ achyanifatchan@yahoo.co.id \\ Payamta \\ Fakultas Ekonomi dan Bisnis, Universitas Sebelas Maret Surakarta \\ kappayamta@yahoo.com
}

\begin{abstract}
This study aims to obtain empirical evidence on the success of e-procurement implementation by the local government, viewed from system and information quality. The implementation success refers to the use and users satisfaction, which contribute to organizations and individuals inside. The research method is quantitative method using questionnaire. The research population is procurement committee in local government, while the sample are the procurement committee members in Surakarta City Government. The data were analyzed using SmartPLS ver.2.0.M3. The results of the statistical analysis show that the system quality does not influence the user satisfaction and use. The information quality has a positive influence to the user satisfaction and actual use. While actual use does not influence the user satisfaction. Moreover, user satisfaction and use also gives a positive influence to the individual impact and the individual impact gives positive impact to the organizational impact.
\end{abstract}

Keywords: e-procurement, system quality, information quality, system use, user satisfaction, individual impact, organizational impact

\section{PENDAHULUAN}

Keputusan Presiden nomor 80 tahun 2003 secara eksplisit telah mengizinkan proses pengadaan melalui e-procurement. Hal inilah yang menjadi dasar lahirnya $e$ procurement sektor publik di Indonesia. Namun pada kenyataanya penerapan $e$ procurement di sektor publik baru dimulai pada tahun 2004. Pada awalnya Badan Perencanaan dan Pembangunan Nasional (Bappenas) ditunjuk sebagai penanggung 
jawab atas sistem ini sebelum Lembaga Kebijakan Pengadaan Barang/Jasa Pemerintah (LKPP) dibentuk berdasarkan Keputusan Presiden nomor 106 pada bulan Desember 2007. Ketegasan e-procurement ini nampak setelah ditetapkannya Peraturan Presiden nomor 54 Tahun 2010 yang mengatur tentang pengadaan barang/jasa pemerintah yang telah diubah dengan peraturan presiden nomor 35 tahun 2011 sebagai perubahan pertama dan peraturan presiden nomor 70 tahun 2012 sebagai perubahan kedua.

Implementasi e-procurement yang merupakan sistem berbasis elektronik mengindikasikan adanya usaha pemerintah untuk memberikan pelayanan yang lebih terpadu dan berkualitas dengan mengikuti perkembangan teknologi. Sistem ini akan berjalan apabila didukung dengan menggunakan seperangkat komputer yang harus terhubung dengan jaringan internet. Sistem yang digunakan merupakan sistem online yang didesain untuk memfasilitasi share informasi atas kebutuhan barang/jasa instansi pemerintah dan pengunggahan dokumen dari pihak penyedia barang/jasa. Pada dasarnya semua sistem yang diterapkan baik pada instansi pemerintah maupun instansi nonpemerintah harus dievaluasi atau diukur tingkat keberhasilan. Keberhasilan atau kesuksesan sistem ini akan menentukan kualitas sistem yang digunakan dan sebagai evaluasi untuk perbaikan dan pengembangan terhadap sistem yang telah diterapkan. Goodhue dan Thompson (1995) menyatakan kesuksesan sistem informasi suatu perusahaan tergantung pada bagaimana sistem itu dijalankan, kemudahan sistem itu bagi para penggunanya dan pemanfaatan teknologi yang digunakan.

Evaluasi terhadap sistem yang digunakan sangatlah penting. Apabila evaluasi hanya diterapkan pada prosedur teknis pengadaan barang/jasa saja, maka tidak bisa diketahui permasalahan lain tentang keberhasilan penerapan e-procurement terutama jika permasalahan tersebut berasal dari sistem yang digunakan. Akan lebih efektif dan efisien jika dilakukan evaluasi keberhasilan sistem, terutama pada penerapan sistem e-procurement. Di dalam penelitian sistem informasi, ada beberapa faktor dalam menilai kesuksesan sistem teknologi informasi. Oleh karena itu telah banyak peneliti yang mengembangkan model kesuksesan sistem informasi ini (Bailey dan Paerson 1983, DeLone dan McLean 1992, Seddon 1997). Belum adanya standar baku menjadikan pengukuran kesuksesan suatu sistem informasi menjadi tidak mudah, harus ada beberapa aspek yang menjadi pertimbangan seperti faktor lingkungan di mana sistem tersebut diterapkan, jenis sistem yang diterapkan dan sebagainya. Meskipun belum ada standar baku untuk mengukur kesuksesan sistem teknologi informasi, tetapi pengukuran ini sangatlah diperlukan. Begitu juga pada instansi pemerintah yang telah menerapkan e-procurement, kesuksesan sistem yang telah diterapkan sangat diperlukan untuk mengukur berjalannya kinerja sektor publik dalam menjalankan e-procurement.

Permasalahan pada sistem e-procurement juga terjadi di LPSE Kota Surakarta, seperti yang terekam pada menu tanya jawab di laman 
Ipse.surakarta.go.id. Permasalahan yang terjadi antara lain rekanan telah mengunggah dokumen sebanyak dua kali, namun dinyatakan tidak ada data oleh pengelola. Kejadian serupa juga dialami oleh rekanan lain di LPSE Kota Surakarta yang telah mengunggah penawarannya dan progres pengiriman mencapai 100 persen, tetapi dokumen yang diunggah tidak berhasil ditampilkan. Selain itu, permasalahan juga terjadi pada rekanan yang telah mendaftarkan secara online di LPSE Kota Surakarta dan telah mendapatkan dua password baru, tetapi kedua password tersebut tidak bisa dipergunakan untuk login. Atas permasalahanpermasalahan tersebut, LPSE Kota Surakarta menjelaskan bahwa laman LPSE sedang mengalami masalah. Hal ini menyebabkan beberapa rekanan kesusahan untuk memasukkan data paket lelangnya.

Berbagai permasalahan tersebut mendorong peneliti untuk mengkaji lebih dalam tentang kesuksesan sistem e-procurement. Untuk mengukur kesuksesan sistem ini tidaklah mudah, karena belum ada standar baku yang mengatur tentang bagaimana mengukur kesuksesan suatu sistem. DeLone dan McLean (1992) mencoba untuk menawarkan suatu model untuk mengukur kesuksesan sistem. Model ini dirasa cocok untuk menilai kesuksesan suatu sistem terbukti telah banyak peneliti menggunakan model ini meskipun memunculkan hasil yang berbeda-beda (Livari 2005; Radityo dan Zulaikha 2007)

Model DeLone dan McLean (1992) merupakan suatu kerangka yang direkomendasikan sehubungan dengan kesuksesan suatu implementasi sistem. Dasar model kesuksesan informasi sistem terdiri dari enam konstruk atau dimensi: (1) kualitas sistem, (2) kualitas informasi, (3) pengguna sistem, (4) kepuasan pengguna, (5) pengaruh individu dan (6) pengaruh organisasional (DeLone dan McLean 1992). Dengan mengevaluasi kesuksesan sistem e-procurement dengan menggunakan model DeLone dan McLean (1992) ini, maka diharapkan pemerintah daerah dapat memperoleh informasi sebagai daftar perbaikan proses pelaksanaan e-procurement.

Hasil penelitian ini diharapkan dapat bermanfaat bagi berbagai pihak yang terlibat dalam proses pengadaan barang dan jasa pada lingkup Pemerintah Kota Surakarta. Pemerintah Kota Surakarta, dapat mengambil informasi dari penilaian persepsi kesuksesan penerapan sistem e-procurement. Selain itu LPSE kota Surakarta beserta LKPP sebagai pengembang dan pelaksana sistem dapat melakukan pengembangan atau perbaikan sistem untuk menjadikannya lebih berkualitas. Penelitian ini juga diharapkan dapat menjadi acuan dan referensi bagi instansi pemerintah daerah lain, universitas dan organisasi publik lain dalam hal penerapan sistem pengadaan barang dan jasa sebagai upaya penciptaan pemerintahan yang bersih, transparan, dan berkualitas. Hasil penelitian juga diharapkan dapat digunakan untuk mengetahui hasil pengujian secara empiris dari model kesuksesan implementasi sistem yang telah dikemukakan oleh Delone dan McLean sehingga dapat berguna bagi pengetahuan akademik yang akan datang. 


\section{KAJIAN PUSTAKA DAN PENGEMBANGAN HIPOTESIS}

\section{Pengadaan Barang/Procurement}

Sistem e-procurement yang efisien tidak lepas dari peranan teknologi online serta adanya laman situs internet yang memberikan kemudahan dalam melakukan transaksi antara instansi dengan konstituen dengan harapan untuk memperoleh keuntungan besar yang disebabkan dari aktivitas efisiensi yang telah dilakukan (MacManus 2002; Wirtz et al., 2010). Menurut Wirtz et al. (2010) definisi eprocurement saat ini tidak membedakan antara sektor swasta dan administrasi publik. Lebih lanjut dijelaskan bahwa tidak ada konsistensi definisi e-procurement pada administrasi publik di Jerman. Bahkan beberapa peneliti maupun badan atau organisasi yang menangani e-procurement telah mendefinisikan istilah $e$ procurement. Seperti halnya Engstorm et al. (2009) mendefinisikan pengertian eprocurement adalah sebagai proses pengadaan barang dan jasa secara elektronik. Selain itu Croom dan Brandon-Jones (2005) mengartikan e-procurement sebagai penggunaan sistem komunikasi secara terintegrasi pada suatu tahap ataupun semua tahap dalam proses pembelian.

Davila et al. (2003) menjelaskan bahwa e-procurement didefinisikan sebagai suatu teknologi yang dirancang untuk memfasilitasi perolehan barang oleh organisasi komersial ataupun pemerintah melalui teknologi internet. MacManus (2002) menjelaskan bahwa procurement memiliki arti yang lebih luas daripada pembelian, dimana procurement menunjukkan fungsi kombinasi dari pembelian atau purchasing, pengendalian terhadap persediaan, pengiriman, penerimaan dan inspeksi serta memberikan tindakan terhadap persediaan. Selain itu, Gerson dalam Lee (2010) mendefinisikan procurement sebagai seluruh proses akuisisi dari pihak ketiga yang meliputi barang, jasa dan proyek konstruksi. Peraturan presiden nomor 54 tahun 2010 yang mengatur tentang pengadaan barang/jasa pemerintah yang telah diubah dengan peraturan presiden nomor 35 tahun 2011 sebagai perubahan pertama dan peraturan presiden nomor 70 tahun 2012 sebagai perubahan kedua menjelaskan bahwa pengadaan secara elektronik atau e-procurement adalah pengadaan barang/jasa yang dilaksanakan dengan menggunakan teknologi informasi dan transaksi elektronik sesuai dengan ketentuan perundang-undangan.

\section{Manfaat dan Tantangan Penerapan Sistem E-Procurement}

Sistem informasi berbasis web terbukti memberikan keuntungan pada instansi yang menerapkan sistem tersebut. Begitu juga dengan penerapan sistem $e$ procurement, yang telah terbukti memberikan banyak manfaat bagi pemerintah yang sudah menerapkan e-procurement ini. Reddick (2004) menjelaskan bahwa ada beberapa manfaat yang diperoleh pemerintah setelah menerapkan sistem $e$ procurement, diantaranya lebih rendahnya biaya administrasi yang digunakan untuk aktivitas pengadaan barang yang diakibatkan dari bisa dikuranginya jumlah orang 
atau pegawai dalam pelaksanaan aktivitas procurement, serta penghematan pada waktu pelaksanaan proses procurement.

Ronchi et al. (2010) meneliti manfaat yang diperoleh dari penerapan eprocurement dengan membandingkan kinerja keuangan dan kinerja organisasi sebelum dan sesudah menerapkan e-procurement. Dari hasil penelitian tersebut dapat dijelaskan bahwa dimensi kinerja keuangan dan kinerja organisasi mengalami perubahan setelah organisasi menerapkan sistem e-procurement. Hasil penelitian ini juga didukung oleh Singer et al. (2009) yang menyatakan bahwa dengan penerapan e-procurement pada organisasi pemerintah, dapat mengurangi biaya administrasi birokrasi yang membantu negara menghindari tugas yang berulang-ulang (seperti registrasi dan sertifikasi kontraktor), menunjukkan adanya mekanisme kontrol yang efisien dan mengurangi kertas kerja.

Banyaknya manfaat yang telah dihasilkan dari penerapan e-procurement memicu adanya celah yang harus diwaspadai oleh organisasi yang menerapkan $e$ procurement tersebut. Harus disadari bahwa berjalannya e-procurement ini memerlukan banyak faktor untuk menghasilkan manfaat yang dapat dirasakan. Tersedianya sumber daya manusia, kompetensi sumber daya manusia untuk menjalankan sistem, fasilitas yang mendukung untuk terlaksananya proses $e$ procurement dan komitmen yang kuat untuk amanah dalam melakukan proses secara benar, menjadikan faktor utama untuk keberhasilan sistem e-procurement.

\section{Pelaksana E-Procurement di Berbagai Negara}

Wirtz et al. (2010) melakukan penelitian tentang hambatan-hambatan yang dihadapi dalam penerapan e-procurement di sektor publik Jerman. Lebih spesifik penelitiannya ingin mengetahui hambatan yang berasal dari individu, eksternal, maupun internal organisasi berkaitan dengan tingkat implementasi. Selain itu juga ada penelitian yang dilakukan oleh Croom dan Jones (2007) meneliti tentang dampak e-procurement di sektor publik UK. Dari penelitian tersebut mereka menemukan bahwa implementasi e-procurement berdampak pada biaya perolehan barang dan jasa. Biaya perolehan barang dikurangi melalui peningkatan sistem procurement, selain itu juga mengurangi maverick buying.

\section{Model Kesuksesan Sistem Infromasi DeLone dan McLean}

Kesuksesan yang dimaksud dalam penelitian ini yaitu merujuk pada penilaian pengguna atas kualitas sistem dan kualitas informasi yang dijabarkan pada kepuasan pengguna dan penggunaan terhadap sistem yang digunakan tersebut. Model DeLone dan McLean (1992) merupakan suatu kerangka yang direkomendasikan sehubungan dengan kesuksesan suatu implementasi sistem. DeLone dan McLean (1992) mengusulkan sebuah kerangka untuk mengukur keberhasilan infomasi sistem dengan membedakan kualitas sistem, kualitas informasi, kepuasan pengguna, kegunaan, dampak individu dan dampak organisasi. Dari beberapa model pengujian kesuksesan 
atas penerapan suatu sistem informasi, model DeLone dan McLean (1992) banyak mendapat perhatian. Berikut adalah gambar dari model DeLone dan McLean (1992).

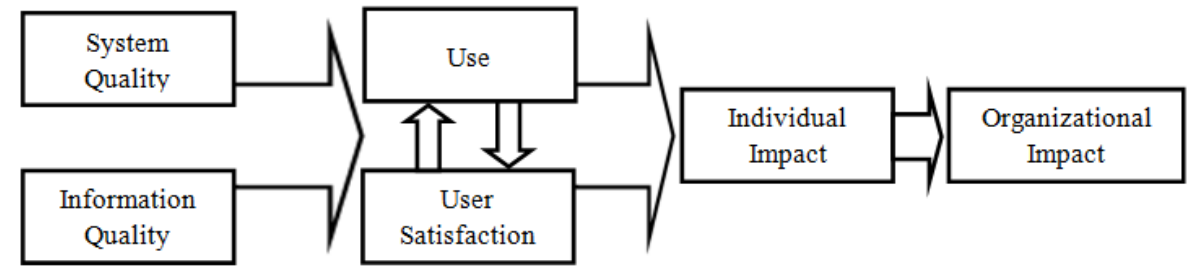

Gambar 1

Model Kesuksesan Sistem DeLone dan McLean (1992)

\section{Pengaruh Kualitas Sistem terhadap Kepuasan Pengguna}

Kesuksesan sebuah sistem informasi yang digunakan oleh suatu instansi dipengaruhi oleh kualitas sistem yang digunakan tersebut (DeLone dan McLean, 2003). Poon dan Wager (2000) menjelaskan bahwa kesuksesan sistem informasi dalam sebuah organisasi diharapkan mampu mengatasi kegagalan-kegagalan yang pernah terjadi dalam organisasi tersebut. Seddon dan Kiew (1996) menyatakan bahwa kualitas sistem berfokus pada tidak adanya gangguan sistem, konsistensi dari bentuk sistem, kemudahan dalam penggunaan sistem, dokumentasi yang mudah dan terkadang berkaitan dengan pembuatan kode-kode yang mudah dimengerti oleh pengguna. Pengguna sistem yang memperoleh hasil yang diinginkan dari sistem yang dipakai tersebut akan merasa lebih puas dan akan terus menggunakan sistem tersebut. Selain itu, sistem yang jarang mengalami error juga akan memberikan kepuasan dengan kata lain kepuasan pengguna akan meningkat jika sistem yang digunakan semakin berkualitas. Berdasarkan paparan tersebut maka dapat dijabarkan dalam hipotesis berikut.

H1: Kualitas sistem (system quality) berpengaruh positif terhadap kepuasan pengguna (user satisfaction).

\section{Pengaruh Kualitas Informasi terhadap Kepuasan Pengguna}

DeLone dan McLean (2003) menyatakan bahwa kesuksesan sebuah sistem informasi dipengaruhi oleh kualitas dari informasi. Selain itu, Jogiyanto (2007) menyatakan bahwa kualitas informasi mengukur kualitas keluaran dari sistem informasi. Seddon dan Yip (1992) mengindikasikan dari hasil penelitian mereka bahwa kualitas informasi merupakan faktor penentu penting terhadap kepuasan pemakai. Selain itu, Livari (2005) menjelaskan dalam hasil penelitiannya bahwa kualitas sistem merupakan prediktor bagi kepuasan pengguna. Penelitian di Indonesia oleh Radityo dan Zulaikha (2007) memberikan penegasan bahwa kualitas informasi menunjukkan output dari sistem informasi yang berhubungan dengan nilai, manfaat dan relevansi dari informasi yang dihasilkan bagi pengguna sistem. Suatu sistem yang dapat memberikan informasi berkualitas yakni lengkap, akurat, up to date dan dapat dipercaya, maka seseorang pengguna akan merasa lebih puas dengan 
informasi yang diperoleh. Berdasarkan paparan tersebut maka dapat dijabarkan dalam hipotesis berikut.

H2: Kualitas informasi (information quality) berpengaruh positif terhadap kepuasan pengguna (user satisfaction).

\section{Pengaruh Kualitas Sistem terhadap Penggunaannya}

DeLone dan McLean (2003) mengungkapkan bahwa tingkat kebermanfaatan sebuah sistem akan terlihat dari frekuensi penggunaan sistem tersebut. Jika Sistem yang dapat digunakan menunjukkan bahwa seorang akan terbantu dengan sistem tersebut. Hal itu menunjukkan bahwa sistem yang ada memiliki kualitas yang baik dan dapat membantu saat bekerja. Seddon dan Kiew (1996) menyatakan bahwa usefulness menunjukkan persepsi dari pengguna tentang kebermanfaatan sistem dalam upaya mengoptimalkan pencapaian para pengguna sistem. Sistem yang berkualitas harus mampu berjalan sesuai dengan fungsi sistem yang telah diterapkan. Pengguna sistem akan cenderung menggunakan sistem secara terus menerus apabila sistem yang digunakan berkualitas. Berdasarkan paparan diatas maka dapat dijabarkan dalam hipotesis berikut.

H3: Kualitas sistem (system quality) berpengaruh positif terhadap penggunaannya (use).

\section{Pengaruh Kualitas Informasi terhadap Penggunaannya}

Poon dan Wagner (2000) menyatakan bahwa kesuksesan sebuah sistem informasi akan berpengaruh terhadap pengambilan keputusan yang diambil oleh para eksekutif organisasi. Namun menentukan kesuksesan sebuah sistem informasi tidaklah mudah. Seddon dan Kiew (1996) menyatakan apabila informasi yang tersedia merupakan informasi yang berkualitas maka pengguna sistem akan sering memanfaatkan informasi tersebut. Li (1997) menjelaskan bahwa apabila sistem menghasilkan informasi yang berkualitas dan kemudian informasi tersebut bermanfaat terhadap pekerjaan penggunanya maka pengguna akan mempromosikan sistem tersebut terhadap rekan kerja lainnya. Berdasarkan paparan tersebut maka dapat dijabarkan dalam hipotesis berikut.

H4: Kualitas Informasi (information quality) berpengaruh positif terhadap penggunaannya (use).

\section{Pengaruh Penggunaan terhadap Kepuasan Pengguna}

Kepuasan pengguna sistem dapat dinilai dari keuntungan yang didapatkan pengguna yang sesuai dan mendukung pekerjaannya. Seddon dan Kiew (1996) menyatakan bahwa kepuasan pengguna menunjukkan kesuksesan atau kejengkelan dalam interaksi yang dilakukan dengan sistem. Selain itu, Jogiyanto (2007) menjelaskan bahwa kepuasan pengguna sistem informasi merupakan respon yang ditampilkan oleh pengguna sistem terhadap penggunaan keluaran informasi sistem 
tersebut. Berdasarkan paparan tersebut maka dapat dijabarkan dalam hipotesis berikut.

H5: Penggunaan (use) berpengaruh positif terhadap kepuasan pengguna (user satisfaction).

\section{Pengaruh Penggunaan terhadap Dampak Individu}

Penggunaan sistem informasi yang telah dikembangkan mengacu pada seberapa sering pengguna memakai sistem informasi. Semakin sering pengguna memakai sistem informasi, biasanya diikuti oleh semakin banyak tingkat pembelajaran (degree of learning) yang didapat pengguna mengenai sistem informasi (McGill et al., 2003). Peningkatan derajat pembelajaran ini merupakan salah satu indikator bahwa terdapat pengaruh keberadaan sistem terhadap kualitas pengguna (individual impact). Leavitt dalam Radityo dan Zulaikha (2007) mencermati bahwa penerapan sistem informasi yang baru akan berdampak pada reaksi yang ditunjukkan oleh perilaku individu dalam organisasi. Reaksi itu berupa munculnya motivasi baru untuk bersaing dan meningkatkan kinerja. DeLone dan McLean (1992) menjelaskan bahwa adanya hubungan antara penggunaan sistem dengan dampak individu yang merupakan suatu hubungan untuk menilai kesuksesan sistem. Berdasarkan paparan tersebut maka dapat dijabarkan dalam hipotesis berikut.

H6: Penggunaan (use) berpengaruh positif terhadap dampak individu (individual impact).

\section{Pengaruh Kepuasan Pengguna terhadap Dampak Individu}

Livari (2005) menjelaskan bahwa jika kepuasan pengguna meningkat, seseorang akan menjadi terdorong untuk meningkatkan kinerjannya. Selain itu Seddon dan Kiew (1996) menyatakan bahwa kepuasan pengguna menunjukkan kesuksesan atau kejengkelan dalam interaksi yang dilakukan dengan sistem. Apabila keuntungan yang didapat dari sistem lebih besar dari yang diharapkan maka terjadilah kepuasan penguna dan sebaliknya. Li (1997) mengungkapkan bahwa persepsi tentang pentingnya sistem menunjukkan bahwa user telah mengambil manfaat dan kepuasan tertentu dari sistem tersebut, sehingga apabila sistem tersebut tidak ada maka kinerja akan menjadi terganggu. Hal ini juga berlaku sebaliknya bahwa dengan adanya kepuasan terhadap pemakaian sistem, maka kinerja akan lebih meningkat. Berdasarkan paparan yang telah dijelaskan diatas maka dapat dijabarkan dalam hipotesis berikut.

H7: Kepuasan pengguna (user satisfaction) berpengaruh positif terhadap dampak individu (individual impact).

\section{Pengaruh Dampak Individu terhadap Dampak Organisasi}

DeLone dan McLean (1992) mengungkapkan bahwa kesuksesan suatu sistem diukur dengan adanya hubungan antara individu yang nantinya akan memengaruhi kinerja organisasi. Hal ini sesuai dengan yang diungkapkan Markus dan Keil (1994) 
yang menyatakan bahwa sebuah kesuksesan sistem akan berdampak pada individu dan organisasi penggunanya, dan selanjutnya dampak individual tersebut berpengaruh terhadap kinerja organisasional. Peningkatan kualitas kinerja organisasi tersebut didasari dari adanya dampak prestasi individu yang juga meningkat. Berdasarkan paparan tersebut maka dapat dijabarkan dalam hipotesis berikut.

H8: Dampak individu (individual impact) berpengaruh positif terhadap dampak organisasi (organizational impact).

\section{Kerangka Pemikiran}

Berdasarkan hipotesis yang telah dijelaskan sebelumnya, maka dapat disusun kerangka pemikiran sebagai berikut:

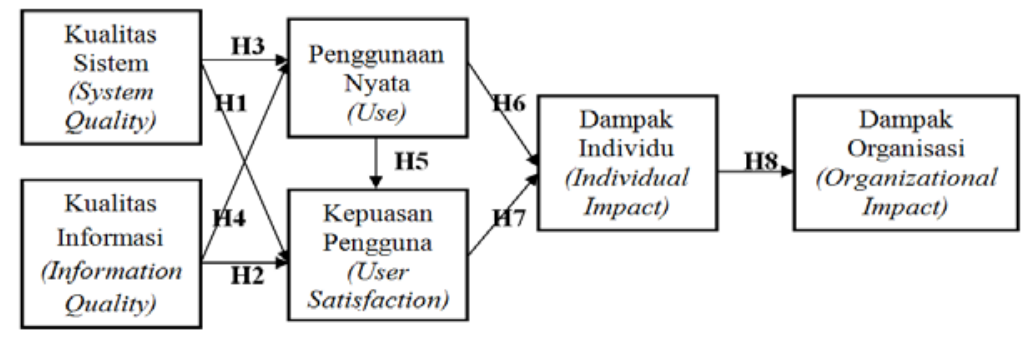

\section{Gambar 2}

Model Penelitian

\section{METODA PENELITIAN}

\section{Sampel dan Data Penelitian}

Populasi dalam penelitian ini adalah panitia pengadaaan barang/jasa di pemerintah daerah yang sudah menerapkan e-procurement. Sampel yang digunakan dalam penelitian ini adalah panitia pengadaan barang/jasa yang berada di Kota Surakarta sebagai pengguna internal dan telah menerapkan sistem e-procurement. Hal yang mendasari Kota Surakarta dalam pemilihan dikarenakan Pemerintah Daerah Kota Surakarta masih baru dalam menerapkan e-procurement sehingga masih banyak memerlukan evaluasi untuk kebaikan sistem. Berdasarkan surat keputsan Wali Kota Surakarta nomor 027/11-J/1/2014 tentang pengangkatan pejabat dan staf unit layanan pengadaan barang/jasa pemerintah di lingkungan pemerintah Kota Surakarta, panitia pengadaan terdiri dari 57 orang.

\section{Definisi Operasional dan Pengukuran Variabel}

Penelitian ini menggunakan 6 variabel dari model yang dikeluarkan oleh DeLone dan McLean (1992) yaitu terdiri dari variabel kualitas sistem, kualitas informasi, kepuasan pengguna, penggunaan, dampak individu dan dampak organisasi. Teknik penggunaan skala pada kuesioner yang digunakan dalam penelitian ini yaitu menggunakan semantic differential scale yaitu pilihan jawaban dibuat suatu perbandingan yang ekstrim (bipolar), responden hanya diminta untuk 
memberikan penekanan sesuai dengan persepsinya. Rentang skala yang digunakan pada penelitian ini yaitu untuk semua variabel masing-masing adalah tujuh digit.

\section{Kualitas Sistem (System Quality)}

Kualitas sistem yaitu kualitas dari kombinasi hardware dan software dalam sistem informasi. Fokusnya adalah performa dari sistem, yang merujuk pada seberapa baik kemampuan perangkat keras, perangkat lunak, kebijakan, prosedur dari sistem informasi dapat menyediakan informasi kebutuhan pengguna (DeLone dan McLean 1992). Indikator yang digunakan merupakan replikasi dari penelitian Livari (2005) terdiri atas lima skala pengukuran yakni: fleksibilitas sistem (system flexibility), kemampuan integrasi sistem (system integration), waktu respon (time to response), perbaikan kesalahan (error recovery) dan kenyamanan akses (convenience of access). Tiap-tiap skala diukur dengan menggunakan empat item, dan tiap item diukur dengan skala Likert satu sampai dengan tujuh.

\section{Kualitas Informasi (Information Quality)}

Kualitas informasi yang dimaksud adalah kualitas informasi yang diukur secara subyektif oleh pengguna yang selanjutnya disebut sebagai kualitas informasi (information quality). Kualitas informasi terkait isu-isu seperti ketepatan waktu, akurasi, relevansi dan format informasi yang dihasilkan oleh sebuah sistem informasi (Kiew dan Seddon 1996). Kualitas informasi dalam penelitian ini diadopsi dari Bailey dan Pearson (1983) yang terdiri dari tujuh skala pengukuran, yaitu: ketersediaan, kelengkapan (completeness), ketepatan (precision), keakuratan informasi (accuracy), konsistensi (consistency) keandalan (reliability) dan kekinian (currency), serta bentuk dari keluaran (format of output). Tiap-tiap skala diukur dengan menggunakan empat item dengan skala Likert satu sampai dengan tujuh.

\section{Penggunaan Nyata (Use)}

Penggunaan nyata (use) merupakan frekuensi seberapa sering suatu sistem informasi digunakan oleh pengguna setelah sistem tersebut diimplementasikan. Hartono (2007) membedakan penggunaan (use) ke dalam penggunaan informasi (information use) dan penggunaan sistem (system use). Mereplikasi item yang digunakan pada penelitian Chin et al. (1988), penelitian ini menggunakan dua item yakni: penggunaan waktu harian (daily used time) dan frekuensi penggunaan (frequency of use), sementara itu tiap item diukur dengan skala Likert satu sampai dengan tujuh.

\section{Kepuasan Pengguna (User Satisfaction)}

Kepuasan pengguna sistem (user satisfaction) adalah perasaan akhir yang berupa rasa senang atau tidak senang yang dihasilkan dari mengumpulkan semua manfaat yang diharapkan seseorang untuk diterima dari interaksi dengan sistem informasi (Seddon dan Kiew 1996). Selain itu, Radityo dan Zulaikha (2007) menjelaskan bahwa kepuasan pengguna sistem (user satisfaction) merupakan respon 
dan umpan balik yang dimunculkan pengguna setelah memakai sistem informasi. Item pertanyaan yang digunakan untuk mengukur kepuasan pengguna (user satisfaction) dalam penelitian ini mereplikasi item pertanyaan yang dipakai oleh Livari (2005) yang diadopsi dari Chin et al. (1988), tiap item diukur dengan skala Likert satu sampai dengan tujuh.

\section{Dampak Individual (Individual Impact)}

Dampak individu (individual impact) adalah pengaruh keberadaan dan pemakaian sistem informasi terhadap kualitas kinerja pengguna secara individual termasuk di dalamnya produktivitas, efisiensi dan efektivitas kinerja (Radityo dan Zulaikha 2007). Livari (2005) menggunakan enam item yang diadopsi dari ukuran persepsi kegunaan (perceived usefulness) oleh Davis (1989) yang juga digunakan dalam penelitian ini, yakni: kecepatan menyelesaikan tugas (speed of accomplishing task), prestasi kerja (job performance), produktivitas (productivity), efektivitas (effectiveness), kemudahan pekerjaan (ease of job) dan bermanfaat dalam pekerjaan (usefull in work). Tiap item diukur dengan skala Likert satu sampai dengan tujuh.

\section{Dampak Organisasi (Organizational Impact)}

Dampak organisasi (organizational impact) yaitu pengaruh keberadaan dan penggunaan sistem informasi terhadap kualitas kinerja organisasi dalam hal ini institusi yang mengembangkan (Hartono 2007). Dalam penelitian ini, variabel dampak organisasi (organizational impact) diukur dengan persepsi pengguna atas pengaruh sistem terhadap kualitas kinerja organisasi dengan menggunakan lima item dan tiap item diukur dengan skala Likert satu sampai dengan tujuh.

\section{Analisis Data}

Pengujian hipotesis dalam penelitian dilakukan dengan menggunakan alat analisis Partial Least Square (PLS) dengan bantuan software SmartPLS versi 2.0 M3. PLS adalah salah satu metoda statistik Structural Equation Modelling (SEM) yang berbasis varian, didesain untuk menyelesaikan regresi berganda ketika terjadi permasalahan spesifik pada data, seperti ukuran sampel penelitian kecil, adanya data yang hilang dan multikolinearitas (Hartono 2011). Menurut Gefen et al. (2000) model (PLS) ini tidak memerlukan asumsi distribusi normal, jumlah sampel yang diperlukan tidak begitu besar, serta bisa diaplikasikan pada penelitian yang bersifat confirmatory maupun exploratory.

Di dalam PLS mengakui dua komponen model kausal, yaitu model struktural dan model pengukuran. Model pengukuran digunakan untuk uji validitas dan reliabilitas, sedangkan model struktural digunakan untuk uji kausalitas (pengujian hipotesis dengan model prediksi). Pengujian hipotesis untuk memprediksi adanya hubungan kausalitas diperoleh melalui uji t-statistic yang dihasilkan dari proses bootstrap. Pengujian dilakukan dengan membandingkan nilai t-tabel dengan nilai $t$ statistics yang diperoleh dari proses bootstrap menggunakan SmartPLS. Hipotesis 
didukung jika nilai t-statistics lebih besar dibandingkan nilai t-tabel. Dengan tingkat keyakinan 95 persen ( $\alpha=5$ persen), maka nilai t-tabel untuk uji hipotesis satu ekor (one-tailed) adalah $\pm 1,68$ (Hair et al., 2010).

\section{HASIL DAN PEMBAHASAN}

\section{Pengumpulan Data}

Data yang digunakan dalam penelitian ini berupa data yang berasal dari kuesioner, hasil dari tanggapan responden yaitu panitia pengadaan barang dan jasa dengan e-procurement di Pemerintah Kota Surakarta. Peneliti memperoleh data yang berisi nama-nama panitia pengadaan di Unit Layanan Pengadaan (ULP) Kota Surakarta. Berdasarkan data tersebut, peneliti membagikan kuesioner dan mengambil pada waktu yang telah disepakati. Kuesioner yang telah dikirim sebanyak 57 dan kuesioner yang kembali sebanyak 54. Terdapat 3 kuesioner yang tidak kembali, karena sampai dengan hari pengambilan kuesioner belum diisi. Hal ini menunjukkan bahwa tingkat pengembalian dari kuesioner yang telah dibagikan 94,74 persen.

\section{Hasil Pengujian Validitas Konvergen}

Validitas konvergen berupa factor loading yang seharusnya nilainya lebih dari 0,5. Item di konstruk yang mempunyai nilai factor loading di bawah 0,50 menunjukkan bahwa konstruk ini kurang valid atau dengan kata lain item-item dikonstruk bukan item yang valid untuk membentuk konstruk, seharusnya tidak dimuat (load) di dalam konstruk.

Tabel 1

Overview Iterasi Algoritma PLS

\begin{tabular}{lccccc}
\hline & \multicolumn{2}{c}{ Uji Validitas } & \multicolumn{2}{c}{ Uji Reliabilitas } & \\
\cline { 2 - 5 } & AVE & $\begin{array}{c}\text { Commu- } \\
\text { nality }\end{array}$ & $\begin{array}{c}\text { Composite } \\
\text { Reliability }\end{array}$ & $\begin{array}{c}\text { Cronbachs } \\
\text { Alpha }\end{array}$ & R Square \\
\hline \hline Kualitas Sistem & 0,502055 & 0,502055 & 0,956422 & 0,952164 & \\
Kualitas Informasi & 0,607413 & 0,607413 & 0,976479 & 0,974888 & \\
Penggunaan Nyata & 0,680835 & 0,680834 & 0,803440 & 0,628470 & 0,063790 \\
Kepuasan Pengguna & 0,692735 & 0,692735 & 0,918404 & 0,889017 & 0,524665 \\
Dampak Individu & 0,704414 & 0,704414 & 0,933880 & 0,913468 & 0,394757 \\
Dampak Organisasi & 0,694565 & 0,694565 & 0,919010 & 0,890005 & 0,541643 \\
\hline
\end{tabular}

Sumber: Output SmartPLS ver 2.0 M3 Tahun 2014

Penelitian ini menggunakan Average Variance Extracted (AVE) lebih besar dari 0,50 dan communality lebih besar dari 0,50 sebagai indikator validitas konvergen. Dengan demikian, indikator tidak akan dihapus jika memiliki skor $A V E$ dan communality di atas 0,50. Berdasarkan data yang diolah, nilai AVE dan communality untuk variabel kualitas sistem, kualitas informasi, penggunaan nyata, 
kepuasan pengguna, dampak individu dan dampak organisasi memiliki nilai di atas 0,50 .

\section{Hasil Pengujian Validitas Diskriminan}

Cara untuk menguji validitas diskriminan dengan indikator reflektif yaitu dengan melihat nilai cross loading untuk setiap variabel harus lebih besar dari 0,50. Cara lain yang dapat digunakan untuk menguji validitas diskriminan adalah dengan membandingkan akar kuadrat dari AVE untuk setiap konstruk dengan nilai korelasi antar konstruk dalam model. Validitas diskriminan yang baik ditunjukkan dari akar kuadrat AVE untuk tiap konstruk lebih besar dari korelasi antar konstruk dalam model (Fornell dan Larcker 1981 dalam Ghozali dan Latan 2012). Nilai cross loading (terlampir) pada penelitian ini menunjukkan bahwa setiap variabel lebih besar dari 0,50. Hal ini berarti bahwa nilai AVE yang dilihat detail dari cross loading tidak perlu dihapus (semua konstruk lebih besar dari 0,50) dan dinyatakan valid. Selain itu hasil pengujian pada cross loading (terlampir) menunjukkan bahwa setiap konstruk lebih besar dari korelasi antar konstruk dalam model.

\section{Hasil Uji Reliabilitas}

Reliabilitas merupakan indikasi mengenai stabilitas dan konsistensi di mana instrumen mengukur konsep dan membantu menilai ketepatan suatu pengukuran (Sekaran 2010). Uji reliabilitas pada penelitian ini menggunakan Cronbach's alpha dan composite reliability yang mana skor reliabilitas Cronbach's alpha harus lebih besar dari 0,50 dan nilai composite reliability harus lebih besar dari 0,70. Dilihat dari tabel diatas menunjukkan nilai Cronbach's alpha lebih dari 0,50 dan composite reliability lebih dari 0,70, sehingga secara umum dapat dinyatakan bahwa instrumen penelitian yang digunakan dalam penelitian ini adalah valid, karena telah memenuhi kriteria validitas konvergen dan diskriminan serta dapat diandalkan, sehingga layak digunakan untuk pengujian hipotesis.

\section{Evaluasi Model dengan Inner Model (Model Struktural)}

Inner model merupakan struktural untuk memprediksi hubungan kausalitas antar variabel laten. Model struktural ini dievaluasi dengan menggunakan koefisien determinasi $\left(\mathrm{R}^{2}\right)$ dan nilai koefisien path. Nilai $\mathrm{R}^{2}$ digunakan untuk mengukur tingkat variasi perubahan variabel independen terhadap variabel dependen. Semakin tinggi nilai $\mathrm{R}^{2}$ berarti semakin baik model prediksi dari model penelitian yang diajukan.

Berdasarkan data yang telah diolah, nilai $\mathrm{R}^{2}$ disajikan dalam Tabel 1. Nilai $\mathrm{R}^{2}$ dari variabel dependen kepuasan pengguna adalah 0,524665, artinya variasi perubahan variabel dependen dapat dijelaskan oleh variabel independen sebesar 52,47 persen, sedangkan sisanya dijelaskan oleh variabel lain di luar model yang diajukan. Nilai $\mathrm{R}^{2}$ dari variabel dependen penggunaan nyata adalah sebesar 0,063790, artinya variasi perubahan variabel dependen dapat dijelaskan oleh variabel 
independen sebesar 6,38 persen, sedangkan sisanya dijelaskan oleh variabel lain di luar model yang diajukan. Nilai $\mathrm{R}^{2}$ dari variabel dependen dampak individu adalah sebesar 0,394757, artinya bahwa variasi perubahan variabel dependen dapat dijelaskan oleh variabel independen sebesar 39,48 persen, sedangkan sisanya dijelaskan oleh variabel lain di luar model yang diajukan. Demikian juga untuk nilai $\mathrm{R}^{2}$ dari variabel dependen dampak organisasi adalah sebesar 0,541643 , artinya variasi perubahan variabel dependen dapat dijelaskan oleh variabel independen adalah sebesar 54,16 persen, sedangkan sisanya dijelaskan oleh variabel lain di luar model yang diajukan.

\section{Hasil Pengujian Hipotesis}

Berdasarkan hasil olah data menggunakan software SmartPLS versi 2.0 M3, diperoleh hasil evaluasi model struktural seperti yang disajikan pada tabel berikut:

Tabel 2

Koefisien Jalur (Mean, STDEV, T-Value)

\begin{tabular}{|c|c|c|c|c|c|}
\hline & $\begin{array}{c}\text { Original } \\
\text { Sample (O) }\end{array}$ & $\begin{array}{c}\text { Sample } \\
\text { Mean (M) }\end{array}$ & $\begin{array}{l}\text { Standard } \\
\text { Deviation } \\
\text { (STDEV) }\end{array}$ & $\begin{array}{c}\text { Standard } \\
\text { Error } \\
(\text { STERR) } \\
\end{array}$ & $\begin{array}{c}\text { T Statistics } \\
(|O / S T E R R|)\end{array}$ \\
\hline $\begin{array}{l}\text { Kualitas Sistem -> } \\
\text { Kepuasan Pengguna }\end{array}$ & 0,183517 & 0,148905 & 0,198450 & 0,198450 & 0,924752 \\
\hline $\begin{array}{l}\text { Kualitas Informasi -> } \\
\text { Kepuasan Pengguna }\end{array}$ & 0,572816 & 0,629698 & 0,180582 & 0,180582 & $3,172049 *$ \\
\hline $\begin{array}{l}\text { Kualitas Sistem -> } \\
\text { Penggunaan Nyata }\end{array}$ & $-0,331876$ & $-0,327458$ & 0,239239 & 0,239239 & 1,387219 \\
\hline $\begin{array}{l}\text { Kualitas Informasi -> } \\
\text { Penggunaan Nyata }\end{array}$ & 0,410693 & 0,425358 & 0,195210 & 0,195210 & $2,103849 *$ \\
\hline $\begin{array}{l}\text { Penggunaan Nyata -> } \\
\text { Kepuasan Pengguna }\end{array}$ & $-0,147589$ & $-0,142444$ & 0,113255 & 0,113255 & 0,303156 \\
\hline $\begin{array}{l}\text { Penggunaan Nyata -> } \\
\text { Dampak Individu }\end{array}$ & 0,242147 & 0,226867 & 0,100719 & 0,100719 & $2,404185^{*}$ \\
\hline $\begin{array}{l}\text { Kepuasan Pengguna -> } \\
\text { Dampak Individu }\end{array}$ & 0,595401 & 0,606793 & 0,075720 & 0,075720 & 7,863191* \\
\hline $\begin{array}{l}\text { Dampak Individu -> } \\
\text { Dampak Organisasi }\end{array}$ & 0,735964 & 0,747984 & 0,061612 & 0,061612 & $11,945102 *$ \\
\hline
\end{tabular}

Sumber: Data diolah tahun 2014

*Signifikan pada tingkat signifikansi 5\% (t-tabel 1,68)

Nilai koefisien path atau inner model menunjukkan tingkat signifikansi dalam pengujian hipotesis. Skor koefisien path atau inner model dapat dilihat pada tabel koefisien jalur (Mean, STDEV, T-Values), yang mana ditunjukkan dengan nilai $t$ statistics. Berdasarkan tabel tersebut dapat disimpulkan bahwa kualitas informasi berpengaruh langsung terhadap kepuasan pengguna dengan koefisien sebesar 0,572816 dan nilai t hitung 3,172049. Hal ini berarti nilai t hitung lebih besar dari nilai t tabel (t tabel 1,68 untuk tingkat signifikansi 5 persen). Kualitas informasi juga berpengaruh langsung terhadap penggunaan nyata dengan koefisien sebesar 0,410693 dan nilai t hitung 2,103849. Penggunaan nyata juga berpengaruh langsung 
terhadap dampak individu dengan koefisien sebesar 0,242147 dan nilai t hitung 2,404185. Kepuasan pengguna juga berpengaruh langsung terhadap dampak individu dengan koefisien sebesar 0,595401 dan nilai t hitung 7,863191. Dampak individu juga berpengaruh langsung terhadap dampak organisasi dengan koefisien sebesar 0,735964 dan nilai t hitung 11,945102. Selain itu, dari hasil pengujian yang telah dilakukan dan disajikan pada tabel koefisien jalur diatas terdapat tiga hubungan yang tidak signifikan yaitu kualitas sistem terhadap kepuasan pengguna, kualitas sistem terhadap penggunaan nyata dan penggunaan nyata terhadap kepuasan pengguna. Hal ini terjadi karena ketiganya memiliki t hitung kurang dari 1,68 (t tabel dengan signifikansi 5\%).

Tabel 3

Hasil Pengujian Hipotesis

\begin{tabular}{|c|c|c|}
\hline & Hipotesis Penelitian & Keterangan \\
\hline H1 & $\begin{array}{l}\text { Kualitas sistem (system quality) berpengaruh positif terhadap } \\
\text { kepuasan pengguna (user satisfaction) }\end{array}$ & H1 tidak didukung \\
\hline H2 & $\begin{array}{l}\text { Kualitas informasi (information quality) berpengaruh positif } \\
\text { terhadap kepuasan pengguna (user satisfaction) }\end{array}$ & H2 didukung \\
\hline H3 & $\begin{array}{l}\text { Kualitas sistem (system quality) berpengaruh positif terhadap } \\
\text { penggunaannya (use) }\end{array}$ & H3 tidak didukung \\
\hline H4 & $\begin{array}{l}\text { Kualitas informasi (information quality) berpengaruh positif } \\
\text { terhadap penggunaannya (use) }\end{array}$ & H4 didukung \\
\hline H5 & $\begin{array}{l}\text { Penggunaan (use) berpengaruh positif terhadap kepuasan pengguna } \\
\text { (user satisfaction) }\end{array}$ & H5 tidak didukung \\
\hline H6 & $\begin{array}{l}\text { Penggunaan (use) berpengaruh positif terhadap dampak individu } \\
\text { (individual impact) }\end{array}$ & H6 didukung \\
\hline H7 & $\begin{array}{l}\text { Kepuasan pengguna (user satisfaction) berpengaruh positif terhadap } \\
\text { dampak individu (individual impact) }\end{array}$ & H7 didukung \\
\hline H8 & $\begin{array}{l}\text { Dampak individu (individual impact) berpengaruh positif terhadap } \\
\text { dampak organisasi (organizational impact) }\end{array}$ & H8 didukung \\
\hline
\end{tabular}
Sumber: Data diolah tahun 2014

Dari tabel hasil pengujian hipotesis yang telah disajikan di atas dapat dijelaskan bahwa dengan adanya informasi yang berkualitas dan semakin baik, maka akan memengaruhi kepuasan pengguna atau kepuasan pengguna dapat meningkat (H2). Selain itu, semakin tinggi kualitas informasi yang diperoleh dari penggunaan sistem akan meningkatkan tingkat penggunaanya dengan kata lain intensitas penggunaan sistem akan meningkat apabila kualitas informasi yang diperoleh dari penggunaan sistem tersebut dapat berkualitas dan berguna (H4). Hasil penelitian ini khususnya pada kualitas informasi mendukung hasil penelitian DeLone dan McLean (1992) dan konsisten dengan penelitian Livari (2005), serta Seddon dan Kiew (1996) yang menyatakan bahwa kualitas informasi merupakan prediktor bagi kepuasan pengguna. Tetapi hasil penelitian ini juga menyangkal pendapat Livari (2005), Seddon dan Kiew (1996) maupun DeLone dan McLean (2003) yang menyatakan 
bahwa semakin tinggi kualitas sistem akan semakin tinggi juga kepuasan pengguna sistem informasi.

Kualitas sistem tidak berpengaruh positif terhadap kepuasan pengguna (H1) dan penggunaannya (H3). Dimungkinkan H1 dan H3 tersebut tidak terdukung karena penggunaan sistem e-procurement bersifat insidental, panitia akan mengakses sistem ini hanya pada saat yang bersangkutan mempunyai paket lelang saja. Di luar itu, panitia bekerja untuk mengurusi pekerjaan lain di masing-masing satuan kerjanya. Selain itu hasil pengujian juga menunjukkan bahwa penggunaan tidak berpengaruh positif terhadap kepuasan pengguna (H5). Pengaruh yang tidak signifikan ini mungkin disebakan sifat pengguna sistem e-procurement yang semi mandatory, artinya pengguna sistem masih diberikan suatu toleransi, meskipun dalam lingkungan yang sifatnya mandatory dan pengguna sistem ini maih memiliki pilihan (e-procurement atau lelang langsung). Hal tersebut bisa terjadi karena panitia masih bisa melakukan pengadaan barang dan jasa melalui lelang langsung, tanpa harus melalui LPSE meskipun lelang tersebut masuk ke dalam kriteria yang harus menggunakan sistem e-procurement atau dengan kata lain melalui LPSE.

Hasil pengujian H6 menunjukkan bahwa semakin intensif pengguna sistem $e$ procurement menggunakan sistem, maka kinerja individu akan meningkat. Pengguna sistem yang menggunakan sistem ini untuk pengadaan barang merasa terbantu, karena dapat mempercepat proses pengadaan sehingga pelaksanaan pengadaan dapat berjalan dengan cepat dan dimungkinkan pengguna tersebut untuk mengerjakan tugas pengadaan yang lain atau pekerjaan yang lain, sehingga produktivitas pengguna sistem akan lebih meningkat. Hasil analisis H6 ini berbeda dengan yang dilakukan Livari (2005) yang menunjukkan tidak ada hubungan antara penggunaan nyata terhadap dampak individu. Penelitian ini juga berhasil membuktikan bahwa kepuasan pengguna berpengaruh positif terhadap dampak individu (H7), yang artinya adalah jika kepuasan pengguna meningkat, seseorang akan menjadi terdorong untuk meningkatkan kinerjannya. Hasil ini mendukung hasil penelitian DeLone dan McLean (1992) dan konsisten dengan penelitian Livari (2005).

Hasil penelitian ini juga membuktikan bahwa dampak individu berpengaruh positif terhadap dampak organisasi (H8). Penggunaan sistem yang telah meningkatkan dampak individu akan berdampak pada organisasi yaitu semakin meningkatkan kinerja organisasi (dapat melalui penghematan biaya dan pemilihan rekanan yang memberikan kualitas barang yang baik dengan harga yang telah ditetapkan). Organisasi yang panitia pengadaannya (individu) mau melaksanakan pengadaan barang dengan sistem e-procurement, akan semakin menghemat biaya yang besar dibandingkan dengan sistem tradisional atau manual. 


\section{SIMPULAN, KETERBATASAN DAN SARAN}

\section{Simpulan}

Berdasarkan pengujian yang telah dilakukan, sebagai hasil dari penelitian dapat disimpulkan bahwa model kesuksesan sistem informasi DeLone dan McLean (1992) yang diuji secara parsial sebagaimana yang telah dilakukan oleh Livari (2005) serta Seddon dan Kiew (1996) tidak semua terbukti secara empiris dalam implementasi sistem e-procurement di Pemerintah Kota Surakarta. Dari delapan hipotesis yang diajukan, terdapat lima hipotesis yang terbukti secara empiris berpengaruh yaitu kualitas informasi terhadap penggunaan nyata dan kepuasan pengguna, penggunaan nyata terhadap dampak individu, kepuasan pengguna terhadap dampak individu, dan dampak individu terhadap dampak organisasi. Sedangkan tiga hipotesis yang lain tidak berpengaruh yaitu kualitas sistem terhadap penggunaan nyata dan kepuasan pengguna, serta penggunaan nyata terhadap kepuasan pengguna.

\section{Keterbatasan dan Saran}

Penelitian ini memiliki keterbatasan yaitu lingkup penelitian yang masih kecil hanya di Pemerintah Kota Surakarta, sementara sistem e-procurement telah diterapkan di organisasi sektor publik lainnya. Untuk penelitian selanjutnya agar memperluas lingkup penelitian seperti di universitas, rumah sakit dan lain-lain. Penelitian ini sebatas evaluasi dari panitia pengadaan barang/jasa di Pemerintah Kota Surakarta, belum bisa digeneralisasikan kepada seluruh pemakai sistem $e$ procurement yang juga melibatkan rekanan. Untuk penelitian selanjutnya agar memasukkan rekanan atau penyedia barang agar evaluasi menjadi utuh. Penelitian ini masih mengesampingkan perilaku pengguna sistem, terutama terkait masalah penyimpangan terhadap proses pengadaan barang dan jasa. Penelitian selanjutnya bisa mengangkat isu-isu praktek korupsi, kolusi dan nepostisme yang berkaitan dengan adanya sistem ini.

\section{DAFTAR PUSTAKA}

Abu-Elsamen, A., G. Chakraborty, dan D. Warren. 2010. A process-based analysis of e-procurement adoption. Journal of Internet Commerce. Vol.9: 243-259.

Bailey, J. E., dan S.W. Pearson. 1983. Development of a tool for measuring and analyzing computer user satisfaction. Management Science. Vol.29.

Croom, S. R., dan A. B. Jones. 2005. Key issues in e-procurement implementation and operation in the public sector. Journal of Public Procurement. Vol.5: 367-387. 
Dai, Q., dan R. J. Kauffman. 2002. Business models for internet-based B2B electronic markets. International Journal of Electronic Commerce. Vol.6 No. 4: 41-72.

Davila, A., M. Gupta dan R. Palmer. 2003. Moving procurement systems to the internet: the adoption and use of e-procurement technology models. European Management Journal. Vol.21 No.1: 11-23.

DeLone, W. H., dan E. R. McLean. 1992. Information system success: the quest for the dependent variable. Information System Research. Vol.3 No.1: 60-95.

2003. The DeLone and McLean model of information systems success: A ten-year update. Journal of Management Information Systems. Vol.19 No. 4: 9-30.

Engstrom, A., A. Wallstrom, dan E. Salehi. 2010. Implementation of public eprocurement in Swedish government entities. Proceedings of the International Multiconference on Computer Science and Information Technology: 315-319.

Ghozali, I., dan H. Latan. 2012. Partial Least Squares: Konsep, Teknik, dan Aplikasi SmartPLS 2.0 M3. Semarang: Badan Penerbit Universitas Diponegoro.

Goodhue, D. L., dan R. L. Thompson. 1995. Task-technology fit and individual performance. M15 Quarterly. Vol.19: 213-236.

Hair, J. F., W. C. Balck, B. J. Babin, dan R. E. Anderson. 2010. Multivariate Data Analysis. Seventh Edition: Pearson.

Hartono, J. 2007. Model Kesuksesan Sistem Teknologi Informasi. Yogyakarta: Penerbit Andi.

Jogiyanto. 2007. Model Kesuksesan Sistem Teknologi Informasi. Yogyakarta: Penerbit Andi.

Lee, M. J. 2010. An exploratory study on the mature level evaluation of eprocurement systems. Journal of Public Procurement. Vol.10 No.3: 405-427.

Livari, J. 2005. An empirical test of the DeLone-McLean model of information system success. The Data Base for Advances in Information System. Vol.36 No.2: 8-27.

MacManus, S. A. 2002. Understanding the incremental nature of e-procurement implementation at the state and local levels. Journal of Public Procurement. Vol.2 No.1: 5-28.

Markus, M. L., dan M. Keil. 1994. If we build it, they will come: designing information systems that people want to use. Sloan Management Review. Vol. 35 No.4: 11-25. 
Mason, R. O. 1978. Measuring information output: a communication systems approach. Information \& Management. Vol.1: 219-234.

McGill, T., V. Hobbs, dan J. Klobas. User-developed applications and information systems success: a test of DeLone and McLean's model. Information Resources Management Journal. Vol.16 No.1.

McLeod, R., dan G. P. Schell. 2008. Sistem Informasi Manajemen. Edisi 10. Jakarta: Penerbit Salemba Empat.

Neef, D. 2001. E-procurement from Strategy to Implementation. United States of America: Prentice Hall.

Peraturan Presiden nomor 54 tahun 2010 tentang Pengadaan Barang dan Jasa Pemerintah.

Peraturan Presiden nomor 35 tahun 2011 tentang Perubahan Pertama Pengadaan Barang dan Jasa Pemerintah.

Peraturan Presiden nomor 70 tahun 2012 tentang Pengadaan Barang dan Jasa Pemerintah.

Radityo, D., dan Zulaikha. 2007. Pengujian model DeLone and McLean dalam pengembangan sistem informasi manajemen (kajian sebuah kasus). Simposium Nasional Akuntansi X. Unhas Makasar.

Reddick, C. G. 2004. The growth of e-procurement in american state governments: A model and empirical evidence. Journal of Public Procurement. Vol.4 No.2: 151-176.

Ronchi, S., A. Brun, R. Golini, dan X. Fan. 2010. What is the value of an IT eprocurement system?. Journal of Purchasing \& Supply Management. Vol.16: 131-140.

Sekaran, U., dan R. Bougie. 2010. Research Methods for Business: A Skill Building Approach. John Wiley \& Sons Ltd.

Seddon, P. B. 1987. Respesification and extension of the DeLone and McLean model of IS success. Information System Research. Vol.8 No.3.

Seddon, P. B., dan M. Y. Kiew. 1996. A partial test and development of DeLone and McLean's model of is success. Australian Journal of Information System: 90109.

Poon, P., dan C. Wanger. 2000. Critical success factors revisited: Success and failure cases of information systems for senior executives. Journal Decision Support System. Vol.30:393-418.

Singer, M., G. Konstantinidis, E. Roubik, dan E. Beffermann. 2009. Does eprocurement save the state money?. Journal of Public Procurement. Vol.9 No.1: 58-78. 
Wirtz, B., S. Lutje, dan P. G. Schierz. 2010. An empirical analysis of the acceptance of e-procurement in the German public sector. International Journal of Public Administration. Vol.33: 26-42. 


\section{LAMPIRAN}

AVE
\begin{tabular}{|c|c|}
\hline & AVE \\
\hline $\begin{array}{c}\text { DAMPAK } \\
\text { INDIVIDU }\end{array}$ & 0,704414 \\
\hline $\begin{array}{c}\text { DAMPAK } \\
\text { ORGANISASI }\end{array}$ & 0,694565 \\
\hline $\begin{array}{c}\text { KEPUASAN } \\
\text { PENGGUNA }\end{array}$ & 0,692735 \\
\hline $\begin{array}{c}\text { KUALITAS } \\
\text { INFORMASI }\end{array}$ & 0,607413 \\
\hline KUALITAS SISTEM & 0,502055 \\
\hline $\begin{array}{c}\text { PENGGUNAAN } \\
\text { NYATA }\end{array}$ & 0,680835 \\
\hline
\end{tabular}

Table of contents

Cronbachs Alpha
\begin{tabular}{|c|c|}
\hline & Cronbachs Alpha \\
\hline $\begin{array}{c}\text { DAMPAK } \\
\text { INDIVIDU }\end{array}$ & 0,913468 \\
\hline $\begin{array}{c}\text { DAMPAK } \\
\text { ORGANISASI }\end{array}$ & 0,890005 \\
\hline $\begin{array}{c}\text { KEPUASAN } \\
\text { PENGGUNA }\end{array}$ & 0,889017 \\
\hline $\begin{array}{c}\text { KUALITAS } \\
\text { INFORMASI }\end{array}$ & 0,974888 \\
\hline KUALITAS SISTEM & 0,952164 \\
\hline $\begin{array}{c}\text { PENGGUNAAN } \\
\text { NYATA }\end{array}$ & 0,628470 \\
\hline
\end{tabular}

Table of contents

Communality
\begin{tabular}{|c|c|}
\hline & communality \\
\hline $\begin{array}{c}\text { DAMPAK } \\
\text { INDIVIDU }\end{array}$ & 0,704414 \\
\hline $\begin{array}{c}\text { DAMPAK } \\
\text { ORGANISASI }\end{array}$ & 0,694565 \\
\hline $\begin{array}{c}\text { KEPUASAN } \\
\text { PENGGUNA }\end{array}$ & 0,692735 \\
\hline $\begin{array}{c}\text { KUALITAS } \\
\text { INFORMASI }\end{array}$ & 0,607413 \\
\hline KUALITAS SISTEM & 0,502055 \\
\hline $\begin{array}{c}\text { PENGGUNAAN } \\
\text { NYATA }\end{array}$ & 0,680834 \\
\hline
\end{tabular}

R Square

Composite Reliability
\begin{tabular}{|c|c|}
\hline & $\begin{array}{c}\text { Composite } \\
\text { Reliability }\end{array}$ \\
\hline $\begin{array}{c}\text { DAMPAK } \\
\text { INDIVIDU }\end{array}$ & 0,933880 \\
\hline $\begin{array}{c}\text { DAMPAK } \\
\text { ORGANISASI }\end{array}$ & 0,919010 \\
\hline $\begin{array}{c}\text { KEPUASAN } \\
\text { PENGGUNA }\end{array}$ & 0,918404 \\
\hline $\begin{array}{c}\text { KUALITAS } \\
\text { INFORMASI }\end{array}$ & 0,976479 \\
\hline KUALITAS SISTEM & 0,956422 \\
\hline $\begin{array}{c}\text { PENGGUNAAN } \\
\text { NYATA }\end{array}$ & 0,803440 \\
\hline
\end{tabular}

Table of contents

\begin{tabular}{|c|c|}
\hline & R Square \\
\hline $\begin{array}{c}\text { DAMPAK } \\
\text { INDIVIDU }\end{array}$ & 0,394757 \\
\hline $\begin{array}{c}\text { DAMPAK } \\
\text { ORGANISASI }\end{array}$ & 0,541643 \\
\hline $\begin{array}{c}\text { KEPUASAN } \\
\text { PENGGUNA }\end{array}$ & 0,524665 \\
\hline $\begin{array}{c}\text { KUALITAS } \\
\text { INFORMASI }\end{array}$ & \\
\hline KUALITAS SISTEM & \\
\hline $\begin{array}{c}\text { PENGGUNAAN } \\
\text { NYATA }\end{array}$ & 0,063790 \\
\hline
\end{tabular}

Table of contents

Gambar 3

Print Screen Hasil Pengolahan Data dengan SmartPLS Ver 2.0 M3 Tahun 2014

Cross Loadings

\begin{tabular}{|c|c|c|c|c|c|c|}
\hline & $\begin{array}{l}\text { DAMPAK } \\
\text { INDIVIDU }\end{array}$ & $\begin{array}{c}\text { DAMPAK } \\
\text { ORGANISASI }\end{array}$ & $\begin{array}{l}\text { KEPUASAN } \\
\text { PENGGUNA }\end{array}$ & $\begin{array}{l}\text { KUALITAS } \\
\text { INFORMASI }\end{array}$ & KUALITAS SISTEM & $\begin{array}{c}\text { PENGGUNAAN } \\
\text { NYATA }\end{array}$ \\
\hline DI_1 & 0,628995 & 0,394377 & 0,417489 & 0,474991 & 0,443547 & $-0,070262$ \\
\hline DI_2 & 0,861310 & 0,638651 & 0,523657 & 0,663800 & 0,513826 & 0,130138 \\
\hline DI_3 & 0,853614 & 0,575350 & 0,502422 & 0,680465 & 0,531560 & 0,236816 \\
\hline DI_4 & 0,890625 & 0,649563 & 0,507741 & 0,675097 & 0,672535 & 0,158079 \\
\hline DI_5 & 0,888738 & 0,670085 & 0,543924 & 0,665165 & 0,646661 & 0,245987 \\
\hline DI_6 & 0,881628 & 0,724320 & 0,427945 & 0,684598 & 0,482024 & 0,245000 \\
\hline DO_1 & 0,646341 & 0,820886 & 0,547204 & 0,734406 & 0,532806 & 0,009914 \\
\hline DO_2 & 0,480480 & 0,778480 & 0,353894 & 0,487660 & 0,433043 & 0,045790 \\
\hline DO_3 & 0,596458 & 0,817200 & 0,348535 & 0,544929 & 0,435157 & 0,010353 \\
\hline Do_4 & 0,601548 & 0,887590 & 0,369773 & 0,597227 & 0,475983 & 0,175054 \\
\hline Do_5 & 0,704617 & 0,858665 & 0,457694 & 0,676867 & 0,515324 & 0,279047 \\
\hline KI_1.2 & 0,426958 & 0,491518 & 0,189000 & 0,577142 & 0,437271 & 0,148196 \\
\hline KI_1.3 & 0,623650 & 0,450871 & 0,333691 & 0,645850 & 0,599585 & 0,037493 \\
\hline KI_1.4 & 0,522230 & 0,539796 & 0,471442 & 0,769155 & 0,617561 & 0,158098 \\
\hline KI_2.1 & 0,531239 & 0,596889 & 0,444822 & 0,794428 & 0,688620 & $-0,021329$ \\
\hline KI_2.2 & 0,619593 & 0,611221 & 0,445563 & 0,795186 & 0,697044 & 0,075445 \\
\hline KI_2.3 & 0,508217 & 0,542595 & 0,543870 & 0,764060 & 0,750404 & 0,008162 \\
\hline KI_2.4 & 0,526350 & 0,548573 & 0,535165 & 0,746269 & 0,714362 & 0,038813 \\
\hline KI_3.1 & 0,532556 & 0,448466 & 0,448324 & 0,773267 & 0,723726 & 0,224343 \\
\hline KI_3.2 & 0,623657 & 0,558914 & 0,528632 & 0,842937 & 0,755830 & 0,256169 \\
\hline KI_3.3 & 0,574233 & 0,533364 & 0,442715 & 0,817806 & 0,664349 & 0,149357 \\
\hline KI_3.4 & 0,481259 & 0,483516 & 0,432199 & 0,805976 & 0,613976 & 0,196774 \\
\hline KI_4.1 & 0,651901 & 0,536234 & 0,486526 & 0,825508 & 0,758889 & 0,141163 \\
\hline
\end{tabular}

\section{Gambar 4}

Print Screen Hasil Uji Hipotesis dengan SmartPLS Ver 2.0 M3 Tahun 2014 


\begin{tabular}{|c|c|c|c|c|c|c|}
\hline KI_4.2 & 0,625852 & 0,529427 & 0,529381 & 0,786915 & 0,697958 & 0,100730 \\
\hline KI_4.3 & 0,658599 & 0,612243 & 0,550274 & 0,833679 & 0,646229 & 0,272512 \\
\hline KI_4.4 & 0,635204 & 0,571058 & 0,532544 & 0,825741 & 0,625767 & 0,182725 \\
\hline KI_5.1 & 0,646516 & 0,699045 & 0,662204 & 0,828895 & 0,648637 & 0,110349 \\
\hline KI_5.2 & 0,630742 & 0,690316 & 0,667542 & 0,813168 & 0,588028 & 0,106607 \\
\hline KI_5.3 & 0,601301 & 0,631996 & 0,596790 & 0,834198 & 0,607242 & 0,061364 \\
\hline KI_5.4 & 0,651428 & 0,597987 & 0,645588 & 0,837537 & 0,621378 & 0,018106 \\
\hline KI_6.1 & 0,604643 & 0,545545 & 0,574858 & 0,757758 & 0,526398 & 0,116768 \\
\hline KI_6.2 & 0,609122 & 0,558005 & 0,573823 & 0,743455 & 0,468074 & 0,124118 \\
\hline KI_6.3 & 0,548687 & 0,519525 & 0,579540 & 0,747127 & 0,530282 & 0,052272 \\
\hline KI_6.4 & 0,684857 & 0,610690 & 0,647093 & 0,844463 & 0,623429 & 0,110751 \\
\hline KI_7.1 & 0,516214 & 0,605868 & 0,588057 & 0,718373 & 0,480241 & 0,137098 \\
\hline KI_7.2 & 0,676054 & 0,666857 & 0,598869 & 0,762491 & 0,587382 & 0,021500 \\
\hline KI_7.3 & 0,612745 & 0,567204 & 0,560675 & 0,699105 & 0,480958 & 0,150290 \\
\hline KI_7.4 & 0,733020 & 0,674685 & 0,606904 & 0,787167 & 0,545991 & 0,161568 \\
\hline KP_1.1 & 0,484356 & 0,393051 & 0,822213 & 0,490406 & 0,425762 & $-0,025510$ \\
\hline KP_1.2 & 0,468774 & 0,493697 & 0,878010 & 0,644812 & 0,543638 & $-0,044913$ \\
\hline KP_1.3 & 0,527128 & 0,462273 & 0,855760 & 0,594791 & 0,486925 & 0,023641 \\
\hline KP_1.4 & 0,509471 & 0,456094 & 0,818181 & 0,654512 & 0,641580 & $-0,196803$ \\
\hline KP_1.5 & 0,412471 & 0,260472 & 0,784217 & 0,475635 & 0,528474 & 0,008234 \\
\hline KS_1.2 & 0,421621 & 0,245633 & 0,489744 & 0,514782 & 0,659846 & $-0,225696$ \\
\hline KS_1.3 & 0,537012 & 0,438740 & 0,514533 & 0,738485 & 0,635921 & $-0,071348$ \\
\hline KS_1.4 & 0,522447 & 0,456870 & 0,327087 & 0,574050 & 0,636819 & 0,010922 \\
\hline KS_2.2 & 0,524357 & 0,447173 & 0,391406 & 0,570057 & 0,662490 & $-0,024351$ \\
\hline$\ldots \ldots$ & ....... & $\ldots \ldots$ & $\ldots \ldots$ & $\ldots \ldots$ & $=\ldots \ldots$ & $\ldots \ldots$ \\
\hline KS_2.3 & 0,451841 & 0,276424 & 0,249652 & 0,515714 & 0,601018 & $-0,113594$ \\
\hline KS_2.4 & 0,450031 & 0,317552 & 0,358250 & 0,552480 & 0,602957 & 0,098255 \\
\hline KS_3.1 & 0,468789 & 0,501066 & 0,637417 & 0,640009 & 0,801356 & $-0,059026$ \\
\hline KS_3.2 & 0,522646 & 0,556321 & 0,589306 & 0,646824 & 0,810563 & 0,030191 \\
\hline KS_3.3 & 0,506329 & 0,458344 & 0,440651 & 0,611120 & 0,725792 & 0,024254 \\
\hline KS_3.4 & 0,324421 & 0,513353 & 0,337982 & 0,589743 & 0,613952 & 0,124397 \\
\hline KS_4.1 & 0,350802 & 0,252754 & 0,421652 & 0,474240 & 0,737960 & 0,002178 \\
\hline KS_4.2 & 0,358030 & 0,387196 & 0,421592 & 0,496655 & 0,772851 & $-0,015202$ \\
\hline KS_4.3 & 0,271579 & 0,352576 & 0,364908 & 0,434526 & 0,669478 & $-0,006530$ \\
\hline KS_4.4 & 0,333675 & 0,308105 & 0,296927 & 0,443133 & 0,688087 & $-0,056526$ \\
\hline KS_5.1 & 0,506412 & 0,512844 & 0,559984 & 0,579489 & 0,801515 & $-0,028089$ \\
\hline KS_5.2 & 0,490380 & 0,466164 & 0,590437 & 0,595337 & 0,832311 & $-0,078133$ \\
\hline KS_5.3 & 0,481748 & 0,340703 & 0,304797 & 0,416558 & 0,735408 & 0,046333 \\
\hline KS_5.4 & 0,599767 & 0,451430 & 0,535633 & 0,588568 & 0,809306 & 0,055909 \\
\hline KS_6.1 & 0,612978 & 0,435797 & 0,402998 & 0,626368 & 0,642598 & 0,157730 \\
\hline KS_6.2 & 0,549396 & 0,417031 & 0,275695 & 0,529004 & 0,640796 & 0,122432 \\
\hline KS_6.3 & 0,464769 & 0,402784 & 0,458894 & 0,579535 & 0,702854 & 0,102908 \\
\hline KS_6.4 & 0,476949 & 0,357197 & 0,488679 & 0,512182 & 0,721971 & $-0,082571$ \\
\hline PN_1 & 0,021791 & $-0,017426$ & $-0,144439$ & 0,036865 & $-0,012107$ & 0,638709 \\
\hline PN_2 & 0,229785 & 0,158457 & $-0,033250$ & 0,161714 & $-0,005774$ & 0,976586 \\
\hline
\end{tabular}

Table of contents

Gambar 4

Print Screen Hasil Uji Hipotesis dengan SmartPLS Ver 2.0 M3 Tahun 2014 (Lanjutan) 